\title{
Enhancement of Waste Foundry Sand Mechanical Properties Through Stabilization Using Slag Based Geopolymer Binder
}

Thandiwe Sithole ( $\square$ nastassias@uj.ac.za )

University of Johannesburg https://orcid.org/0000-0002-0075-4238

\section{Tebogo Mashifana}

University of Johannesburg - Doornfontein Campus

Nelson Tsotetsi

University of Johannesburg - Doornfontein Campus

\section{Research}

Keywords: Granulated furnace slag, Geopolymers, single alkaline activators, geopolymer binder, unconfined compressive strength, Microstructure

Posted Date: April 8th, 2021

DOI: https://doi.org/10.21203/rs.3.rs-366174/v1

License: (a) (1) This work is licensed under a Creative Commons Attribution 4.0 International License. Read Full License 


\section{Abstract}

It is of paramount importance to minimize carbon emission generated from production of major building and construction materials used worldwide such as bricks and Ordinary Portland cement to achieve sustainability requirements. In this paper, the binding properties of the synthesized granulated blast furnace slag (GBFS) geopolymers were assessed by developing eco-friendly waste foundry sand bricks. Four different mix designs were prepared by blending GBFS based geopolymer binder with aggregates (waste foundry sand and crushed stones). The amount of GBFS geopolymer binder was varied from 0 to $40 \%$. The developed specimens were evaluated for mechanical properties, durability, structural performance, and environmental impact. The specimens synthesised with $40 \%$ GBFS geopolymer binder at a L/ S ratio of $15 \%$ and cured at $80{ }^{\circ} \mathrm{C}$ achieved the highest UCS of $12 \mathrm{MPa}$. The results showed that the developed specimens are acid resistant which suggest that they can be used in corrosive environments and do not pose any threat of environmental pollution for long-term use. In conclusion, GBFS-based geopolymers can be used as binders to fabricate building bricks that meet the minimum requirement of ASTM C62-10 that can be used in negligible weathering conditions.

\section{Introduction}

Portland Ordinary cement (OPC) and bricks are major building and construction materials worldwide [1]. The annual global cement production (OPC) and bricks has reached approcimately 4 billion tonnes and 1391 billion units respectively [2, 3]. The demand is expected to continuously increase due to rapid worldwide growth of urban infrastructure development [4]. Global cement production is estimated to increase from 4.83 billion metric tons by 2030 and grow by $45 \%$ in 2050 than the current production $[5,6]$. Conventional bricks are produced from ordinary Portland cement (OPC), concrete or from clay with high temperature kiln firing [3]. Manufacturing of OPC and clay fired bricks not only are energy intensive but releases enormous amounts $\mathrm{CO} 2$ and NOx responsible for global warming [7]. To be specific, cement production industries around the world release greenhouse gases approximated to 1.5 billion tons each year into the atmosphere. Moreover, there is about $30 \%$ of $\mathrm{CO} 2$ in the atmosphere [8]. Moreover, the process of obtaining clay consumes vast amount of energy and generate large quantities of waste material that needs to be landfilled; the land for landfilling is reducing all over the world $[9,10]$. Most of the developing countries have severe energy crisis causing power cuts and this puts more strain on the energy grid [11]. To address challenges above-mentioned many researchers $[12,13,14,15,16,17,18,19$ and 20]. have studied the reuse industrial waste such as; Fly ash, mine tailings, foundry sand, basic oxygen furnace slag, metakaolin and granulated furnace slag use of waste material to manufacture brick using geopolymerisation technology Geopolymers (GPs) are inorganic polymer products from the reaction between synthetic or natural aluminosilicate materials such as fly ash (FA) or metakaolinite and alkaline activators such as silicates, hydroxides of sodium and potassium at relatively low to nearly elevated temperatures [21, 22 and 23]. Although geopolymers are considered as radical materials that have excellent characteristics such as high unconfined compressive strength, excellent fire resistance, low shrinkage, low liquid limit and energy efficient during production [24]. Their environmental impact 
depends on the alkaline activating agents and the material used as precursors [25]. Most of the studies conducted in geopolymerisation focused on the use of combination of silicates with either sodium or potassium hydroxide solution to produce geopolymer bricks or binder. However, feasibility studies of using a single alkaline activator to produce a geopolymer binder and evaluate its binding properties by stabilizing other waste material to manufacture building bricks are scarce and limited. Temuujin et al. studied the geopolymerisation of GBFS using $\mathrm{NaOH}$ and $\mathrm{NaSiO} 3$ as alkaline activators which achieved UCS up to $70 \mathrm{MPa}$ after 28 days of curing at ambient temperature [26]. Mejia et al. developed geopolymeric binder by blending GBFS and fly ash and used sodium silicate $\mathrm{Na2SiO3} \mathrm{as} \mathrm{the} \mathrm{alkaline}$ activator, the UCS was around 30-40 MPa after 7 days of curing at ambient temperature. Mejia et al. further blended GBFS and metakaolinite, used silica reactive source and $\mathrm{NaOH}$ as activators, the resulting UCS was around $60 \mathrm{MPa}$ after 28 days of curing [27]. Robayo-Salazar et al. calcined a Colombian based $\mathrm{NP}$ and blended it with $30 \%$ GBFS, using combined alkaline activators $\mathrm{NaOH}$ and $\mathrm{Na2SiO3,} \mathrm{UCS} \mathrm{results} \mathrm{of}$ the cement were up to $45 \mathrm{MPa}$ after 28 days or curing at ambient temperature [28]. Rashad et. al. proved that alkaline activating Metakaolin with $\mathrm{Na} 2 \mathrm{SiO} 3$ and $\mathrm{NaOH}$, after 28 days of curing at ambient temperature, UCS results of the binder activated with $\mathrm{NaOH}$ was only $27 \mathrm{MPa}$ whereas that activated with $\mathrm{Na} 2 \mathrm{SiO} 3$ was as high as $170 \mathrm{MPa}$ [29]. Falah et al. reported that using aqueous $\mathrm{Na2SiO3}$ instead of $\mathrm{NaOH}$ improves geopolymerisation and the mechanical strength of geopolymeric binder [30]. Even though $\mathrm{NaSiO} 3$ favors the geopolymerisation and offers excellent mechanical strength, silicates (in either liquid or solid form) have highest negative environmental but produced the binder with good mechanical strength [29]. Tekin et al. [31] reported that sodium hydroxide $(\mathrm{NaOH})$ is more eco-friendly solution than sodium metasilicate (NaSiO3) in terms of $\mathrm{CO} 2$ emission. Hence, Sithole et al. studied the feasibility of using a single alkaline activator $\mathrm{NaOH}$ to successfully develop GBFS-based geopolymer binder that achieved unconfined compressive strength of $72 \mathrm{MPa}$ at elevated temperatures [11]. Sithole et al study demonstrated that the synthesised geopolymer specimen is environmentally friendly and complies with American Society for Testing Materials (ASTM) C34-13, C129-14a and South African standard (SANS227: 2007). However, in most of the studies discussed above the UCS was used as a criterion to decide if the developed geopolymer can be classified as a binder; the binding properties of the developed geopolymers were not investigated. This research therefore seeks to address the above-mentioned challenges by using by-products granulated blast furnace slag to develop a binder that can replace OPC used in production of conventional bricks. Since river sand access is also becoming more costly and limited due to illegal dredging therefore waste foundry sand was used as an alternative raw material in production of building bricks and evaluating GBFS geopolymer binding properties [32]. Waste foundry sand (WFS) is waste material which is produced about 0.6 tons per 1 ton of foundry industry production [33]. While it cannot be recycled or reused, it will be disposed of in landfills. In addition, due to the fast dwindling of natural resource such as clay globally there is a need to preserve clay resource by exploring the reuse of waste as raw material in production both cementitious material and bricks. Re-use of wastes as raw materials not only conserves energy but it is also a commercially viable pollution control and a solution to a waste disposal problem [34]. Industrial ecology (IE), a fast-growing discipline, advocates that the most efficient way to achieve sustainable development is via the imitation of the natural world [35]. Therefore, re-use of by-products and waste products from anthropogenic processes is heavily supported to conserve the 
environment. This research therefore seeks also to achieve a zero waste discharge model by beneficiating of waste foundry sand by using it as a main raw material in production of bricks and use GBFS to develop a binder so that no waste is generated. About section numbering, the abstract is not included in section numbering. Subsection should be numbered 1.1. (then 1.1.1., 1.1.2., ...), 1.2., etc. Each heading should appear on its own separate line.

\section{Materials And Methods}

\subsection{Raw materials characterization}

GBFS was collected from slag granulation plant of ArcelorMittal steel production in South Africa. Waste foundry sand was used as fine aggregate and crushed stone as course aggregate. Prior to initial characterisation, GBFS was milled using a vibratory disc mill (RS 200) for about 5 minutes to obtain the desired particle size to increase surface area for improved reactivity. The alkaline activator was $98 \%$ pure sodium hydroxide $(\mathrm{NaOH})$ provided by Rochelle chemicals also in South Africa. Table 1 lists the physical properties of GBFS-based geopolymeric binder and sand. On the other hand, chemical composition of raw materials are shown in Table 2. The major constituents of GBFS based geopolymeric binder were the oxides of aluminium, calcium and sodium while silicon dioxide was prominent in both materials.

Table 1

Physical properties of raw materials

\begin{tabular}{|lllll|}
\hline Physical property & Colour & Shape & $\begin{array}{l}\text { Average particle size } \\
(\mu \mathrm{m})\end{array}$ & $\begin{array}{l}\text { Specific } \\
\text { gravity }\end{array}$ \\
\hline Waste foundry Sand & Yellow & $\begin{array}{l}\text { Subangular to } \\
\text { rounded }\end{array}$ & 2.79 \\
\hline $\begin{array}{l}\text { GBFS-based geopolymeric } \\
\text { binder }\end{array}$ & White & & 2.93 \\
\hline
\end{tabular}


Table 2

Chemical properties of raw materials

\begin{tabular}{|c|c|c|}
\hline Chemical composition (\%) & GBFS based geopolymeric binder & Sand \\
\hline $\mathrm{Al}_{2} \mathrm{O}_{3}$ & 9,147 & 2,378 \\
\hline $\mathrm{BaO}$ & 0,172 & - \\
\hline $\mathrm{CaO}$ & 29,991 & 5,416 \\
\hline $\mathrm{Cl}$ & 0,023 & 0.019 \\
\hline $\mathrm{Cr}_{2} \mathrm{O}_{3}$ & 0,018 & 0.101 \\
\hline $\mathrm{CuO}$ & - & 0.006 \\
\hline $\mathrm{Fe}_{2} \mathrm{O}_{3}$ & 0,533 & 0.845 \\
\hline $\mathrm{K}_{2} \mathrm{O}$ & 0,812 & 0.273 \\
\hline $\mathrm{MgO}$ & 4,92 & 0.75 \\
\hline $\mathrm{MnO}$ & 0.777 & 0.083 \\
\hline $\mathrm{Na}_{2} \mathrm{O}$ & 14.914 & 0.401 \\
\hline $\mathrm{Nb}_{2} \mathrm{O}_{5}$ & - & - \\
\hline $\mathrm{NiO}$ & 0.010 & 0.017 \\
\hline $\mathrm{P}_{2} \mathrm{O}_{5}$ & 0.009 & 0.033 \\
\hline $\mathrm{Rb}_{2} \mathrm{O}$ & 0.004 & - \\
\hline $\mathrm{SO}_{3}$ & 1.466 & 0323 \\
\hline $\mathrm{SiO}_{2}$ & 24.076 & 89.047 \\
\hline SrO & 0.238 & 0.021 \\
\hline $\mathrm{TiO}_{2}$ & 0.687 & 0.135 \\
\hline $\mathrm{Y}_{2} \mathrm{O}_{3}$ & 0.011 & 0.002 \\
\hline $\mathrm{ZnO}$ & - & - \\
\hline $\mathrm{ZrO}_{2}$ & 0.042 & 0.012 \\
\hline LOI & 12.15 & 0.14 \\
\hline
\end{tabular}


Table 3

Geopolymeric concrete mix design

\begin{tabular}{|lllll|}
\hline Binder $(\mathbf{g})$ & Sand $(\mathbf{g})$ & Crushed stone (g) & Total (g) \\
\hline 60 & 120 & 120 & 300 \\
\hline 75 & 112.5 & 112.5 & 300 \\
\hline 90 & 105 & 105 & 300 \\
\hline 120 & 90 & 90 & 300 \\
\hline
\end{tabular}

\subsection{Experimental procedure}

The dry ingredients (binder, sand crushed stone) were mixed together at different ratios as shown in Table 3 to find the mix proportion that enhances the binding properties of the developed binder. The optimum mix ratio was used to establish optimum liquid to solid ratio $(L / S)$ and curing temperature. The UCS was used as a criterion for choosing the optimum curing conditions.

\subsection{Preparation of the geopolymeric binder}

(GBFS) was used as aluminosilicate precursor for production of geopolymer binder. $\mathrm{NaOH}$ pellets were added to distilled water to produce alkaline solution. The optimum curing concentration and liquid to binder (L/S) ratio were found to be $15 \mathrm{M}$ and 0.15 respectively from the previous study by Sithole et al. [11]. The alkaline activator solution was allowed to cool at room temperature for $24 \mathrm{~h}$. After 24 hours, the alkaline solution was mixed with GBFS, the mixture was stirred continuously until homogeneity was attained and the binder was cured at optimum curing as reported by Sithole et al. [11]

\subsection{Preparation of the geopolymer specimens}

The dry ingredients (binder, waste foundry sand and crushed stone) were mixed at different binder to aggregate ratios as shown Table 3. Water was then added gradually and blended with the dry mixture until homogeneous mixture was attained. The mixtures were then transferred in a $50 \times 50 \times 50 \mathrm{~mm}^{3}$ steel moulds, compacted using a vibration table to reduce entrapped air and kept protected after casting to avoid water evaporation. All samples were covered with plastic, cured at room temperature for $24 \mathrm{~h}$. After $24 \mathrm{~h}$ the specimens were demoulded and cured at different temperatures ranging from $40{ }^{\circ} \mathrm{C}-90{ }^{\circ} \mathrm{C}$ for a period of 5 days.

\subsection{Unconfined compressive strength testing}

The unconfined compressive strength (UCS) of the synthesised geopolymer bricks were tested by placing a brick between the bearing surfaces of the machine to apply the maximum load of $100 \mathrm{kN}$ to the opposite sides of the cube cast. The load was gradually applied without shock at a rate of $2 \mathrm{~mm} / \mathrm{minute}$ until the specimen failed.

\subsection{Equipment}


The XRF (Rigaku ZSX Primus II) was used to analyse chemical composition of the geopolymeric binder and cured bricks. X-Ray Diffraction (XRD) was used to quantify and identify minerology and SEM (Tescan Vega 3 XMU 1) was used capture the surface morphology of specimen. The cyber plus compression machine was used to test the unconfined compressive strength (UCS) of the geopolymers mortar and concrete.

\subsection{Open porosity and absorption rate}

The water absorption test was performed according to(ASTM C373-14 on specimens cured using optimum curing conditions. The mass of the specimens were weighed and recorded as dry mass $\left(M_{d}\right)$; the samples were subsequently immersed in deionised water for a period of 24-hours. After 24 hours the specimens were removed from water wiped off any water found on its surface and weighed again to find mass of the wet sample $\left(W_{w}\right)$.

$W=\left(M_{w}-M_{d}\right) / M_{d} \times 100 \%(1)$

\subsection{Toxicity characteristic leaching procedure (TCLP)}

TCLP test was carried out as per USEPA method 1311 on the respective geopolymeric specimens. A modified static USEPA 1311 was used to determine the long-term leaching characteristic of the geopolymeric binder. The cured specimens without being crushed were placed in a column and completely covered with an extraction buffer of acetic acid and sodium acetate ( $\mathrm{pH} 4.93 \pm 0.05)$. The static extraction was left for 30 days. At the end of the 30 days, the extraction buffer was withdrawn completely before being acidified with nitric acid and subsequent metal analysis with Inductively coupled plasma mass spectrometry (ICP-MS).

\section{Results And Discussion}

\subsection{Effect of binder to aggregate ratio on UCS}

Figure 1 shows the UCS results of geopolymer specimens casted with different binder to aggregate (sand and crushed stone) ratio. The results reveal a linear increase of UCS with increasing binder to aggregate ratio. There was a $19 \%$ increase in UCS between specimens prepared with $20 \%$ and $40 \%$ binder. The noticeable increase in UCS with higher binder to aggregate ratios is probably due to increase in binding products between the interface of sand and the geopolymer binder [36]

Another reason may be that higher sand particles in the mixture consumes a lot of water necessary for hydration reactions of the binder, this significantly affects the formation of C-S-H leading to lower UCS. Furthermore, higher percentage of sand in the concrete specimen may have required a more water for adequate hydration of the binder [37]. Makul et al [38] developed cement and waste foundry sand concrete and found that increase in sand percentage up to 50 percent reduced the UCS. These findings corroborate with finding reported by Phoo-Ngernkham et al [39]. Similar literature published by Nath also 
confirms that increasing binder \% in the mixture plays a major role in formation of more hydration products that enhances the binding properties and UCS of the geopolymeric concrete [40].

\subsubsection{SEM analysis of concrete samples with different binder content}

Figure 2 depicts the SEM images of sand, binder and concrete specimens with binder to sand ratio of 20 $\%$ and $40 \%$. The morphology of $20 \%$ binder to aggregate specimen revealed a rather fragile matrix with more non-reacted particles. The observation made on this microstructure could be related to effect of less binding materials available to bind sand particles hence less dense matrix with lower UCS. The micrograph show that specimen synthesised with $40 \%$ binder to aggregate ratio had denser microstructure suggesting more connectivity between the binder and aggregate hence improved UCS with increase in binder to aggregate ratio [41]. The higher percentage of binder favoured the hydration reactions that enhanced better formation of C-S-H gel that improved interfacial transition zone (ITZ) between the binder and the concrete specimen [42].

\subsubsection{FTIR analysis of specimens with different binder content}

Figure 3 depicts the FTIR spectra of sand, binder, and specimens prepared with $20 \%$ and $40 \%$ binder to aggregate ratio. The results show that specimens had little or insignificant amount of water within the matrix due to lack of $\mathrm{H}-\mathrm{O}-\mathrm{H}$ vibrations around $3600 \mathrm{~cm}^{-1}$ [43]. The absorption bands around $500 \mathrm{~cm}^{-1}$ usually indicates the bending mode of Si-O-T ( $\mathrm{T}$ may be Al or Si and in some cases $\mathrm{Ca}$ ) [44]. The band frequency of the sample with $20 \%$ binder to aggregate ratio around $300 \mathrm{~cm}^{-1}$ to $500 \mathrm{~cm}^{-1}$ was low, suggesting that the formation of geopolymer products was inversely proportional to the band frequency. However, the results show that the specimen synthesised with $40 \%$ to binder to aggregate ratio had the broad band frequency around $300 \mathrm{~cm}^{-1}$ to $500 \mathrm{~cm}^{-1}$. This broad band is related to quartz mineral [44]. The specimen synthesised with $20 \%$ aggregate to binder ratio had insignificant band around $800 \mathrm{~cm}^{-1}$. However the specimen with $40 \%$ binder to aggregate ratio had a broad band, this band corresponds to $\mathrm{Si}$ O-Al vibration [45 and 46]. Thus, the increased UCS with increase in binder can be explained by the Al and $\mathrm{Ca}$ increase while $\mathrm{Si}$ levels decrease. This increased $\mathrm{AlO}_{4}$ and $\mathrm{C}-\mathrm{A}-\mathrm{S}-\mathrm{H}$ products responsible for better mechanical performance [47].

\subsection{The effect of Liquid/Solid (L/S) ratio on UCS of concrete samples}

Figure 4 shows the UCS of geopolymeric concrete with different L/S ratio, UCS decreases with increase in $\mathrm{L} / \mathrm{S}$. The liquid to solid ratio of 0.15 was sufficient to yield the optimum paste mixture and produce samples with good mechanical performance mostly due to good binding properties between the sand and the developed binder. The workability and flow of the paste was increased with increased L/S ratio from 0.15 to 0.23 but the UCS was reduced by $28 \%$, the results are in agreement with work by Shoaei et 
al. [48]. The lower UCS with increasing L/S could be explained by increased pore size and volume increasing at a greater rate with increasing liquid content in the samples that caused poor binding properties of the binder [49]. Samantasinghar et al. concluded that solution to binder ratio below optimum causes poor hydrolysis of the solid precursor while high L/S ratio causes voids in the matrix that causes lower UCS [50]. Decreasing the liquid to solid ration to $12 \%$ resulted in a very poor workability that is difficult to cast hence no results are shown.

\subsection{The effect of different curing temperature on UCS}

Figure 5 shows the UCS results of geopolymer specimens cured at different temperatures. The results indicate that an increase in temperature from $40{ }^{\circ} \mathrm{C}-80^{\circ} \mathrm{C}$ enhanced the UCS of samples by $59 \%$. This indicates that an increase in curing temperature from 40 to $80^{\circ} \mathrm{C}$ favors the dissolution of solid precursors in alkaline medium, which causes high polycondensation and subsequently compact and dense structure. This latter mentioned statement therefore qualifies the trend observed in the aforementioned results [45]. However, the UCS decreased at temperatures beyond $80^{\circ} \mathrm{C}$, higher temperatures (above $80^{\circ} \mathrm{C}$ ) affected C-A-S-H and N-A-S-H formation that may result in microstructure of specimen much coarser and possible micro cracks [51]. This was possibly attributed to less dissolution rate of magnesium $(\mathrm{Mg})$, silica $(\mathrm{Si})$ and Alumina $(\mathrm{Al})$ elements that hindered formation of more materials and dissolution of crystalline phases, hence the lower UCS [52]. In addition, evaporation at $90{ }^{\circ} \mathrm{C}$ may have liquid content below the optimum L/S ratio and this negatively affected binding process between the sand and the binder hence lower UCS [48].

\subsubsection{SEM analysis}

Figure 6 depicts the SEM images of sand, binder and mortar samples cured at different temperatures. The sample cured at $40{ }^{\circ} \mathrm{C}$ shows a heterogeneous and less dense micrograph than specimens cured at higher temperature. The sample cured at $60{ }^{\circ} \mathrm{C}$ exhibited a rather coarse microstructure suggesting some voids and poor binding properties between the particles. This may be the result of incomplete or poor dissolution of aluminosilicate materials in the geopolymer matrix [53]. Whilst a sample cured at $80{ }^{\circ} \mathrm{C}$ showed a dense structure, strongest compaction and more homogeneity because of high formation of more binding materials. Furthermore, curing at $80{ }^{\circ} \mathrm{C}$ promoted a formation of more Na-polyferrosialate (Si-O-(Fe)Al) and Na-polysialate (Si-O-Al) products that allow a development of compact structure supporting the enhancement in UCS and mechanical performance [52]. For the samples cured at $90^{\circ} \mathrm{C}$, there is a presence of minor voids which may be caused by more evaporation of the liquid due to high temperature leading to poor agglomeration between the particles in the matrix. The presence of minor voids may have caused precipitation of some binding materials and could explain the lower UCS gained on the samples cured above $80^{\circ} \mathrm{C}$ [52].

\subsection{Durability}

Durability in construction industry is one of the vital criteria or principle for the design of geopolymers and concrete structures. Durable structures conserve natural resources and the environment by 
minimizing waste and negative footprint of repair and maintenance. Some of the parameters that may reduce the life span of cementitious materials is immersion in water and interaction with acidic or basic aggressive environments [54].

\subsubsection{The effect of wet dry cycles on UCS}

Figure 7 shows the results of wet-dry cycles of speciments up to 30 cycles. It can clearly be seen that there was a decrease in UCS for the first 15 cycles. After the 15th cycle, the UCS started to increase until the 24th cycle [28]. The tested specimen probably did not have dense microstructure and had many pores and micro cracks at the beginning cycles due to expansion upon drying. This may have caused delayed and secondary formation of ettringite with heterogeneous particles that caused coarser microstructure [48]. This justifies the decreasing UCS at the beginning cycles. On the other hand, sodium may have reacted with more calcium materials from the geopolymeric binder to create more ettringite and gypsum with long-term cycles. Ettringite and gypsum are the main hydration products of cement and continuously filled the internal pores, restrained the propagation of more major cracks and formed more homogeneous geopolymeric matrix matrix. This led to a more stable structure with more $\mathrm{C}-\mathrm{S}-\mathrm{H}$ materials to enable the samples sustain good durability both in wet and dry environments [54].

\subsubsection{The effect of water soaking on UCS}

Figure 8 shows the influence of water soaking of concrete samples on UCS. UCS relatively increased with duration of water soaking days until UCS of $16.28 \mathrm{MPa}$ on the 18 days of soaking was reached. This may be attributed to absorbed water restraining development of cracks to some extend and this reduced the rate of deformation of soaked samples. Jang et al. [55] acknowledged that the viscous resistance of free water slows down the creation and expansion of micro cracks. On the other hand, the absorbed water may have lowered Van der Waals forces between the samples after 18 days of water soaking. This had an adverse effect on C-S-H formation and connectivity between the binder and the aggregate, this negatively affected mechanical performance of the samples and resulted in reduction UCS. In addition, micro cracks may have propagated and coalesced into many other several major cracks on the samples leading to efflorescence noticed in Fig. 9 and further reduction in UCS [56].

\subsubsection{The effect of acid attack on UCS}

Figure 11 presents the acid attack resistance test results. The samples had the highest UCS at 14 days of immersion in the acid indicating that the corrosion rate was most likely lower than the hydration reaction rate. This may also be due to the existence of more stable binding compounds (N(C)-A-S-H) and less calcium salts that made the matrix more resistant to acid attack [54]. The contact between the samples and acidic media probably leached calcium ions from calcium-containing phases such as C-A-S-H and NA-S-H in hardened concrete and subsequently reducing the binding properties of the developed binder. 
The hydration of calcium silicate formed calcium salts that lead to increase in porosity of the samples and reduction in durability performance, this is evident with reduction in UCS after 14 days of acid attack [54]. Furthermore, the acid attack may have accelerated due to more chemical reaction of corrosive sulfate ions with calcium compounds of the binder to form calcium sulfate that lead to internal disintegration stresses and spalling of surface layers as seen on Fig. 11. According to Aygörmez et al. the acid is responsible for disintegration of oxy-aluminum bridge (Si-O-Al) bonds that are responsible for strengthening the bonds within the matrix [57]. The residual UCS of the samples during the acid attack test depends mainly on the initial strength and the cross sectional area of the sample damaged by the acid attack. Moreover, there is no uniform change in the shape of the cubic sample during the acid exposure and this leads to errors in UCS test [58].

\subsection{The water absorption test}

Table 4

A 24-hour soak of specimen properties

\begin{tabular}{|ll|}
\hline \multicolumn{2}{|l|}{ Specimen prepared with $\mathbf{4 0} \%$ binder } \\
\hline Dry mass of cured sample $(\mathrm{g})$ & 228.18 \\
\hline Mass of cured sample after 24-hour soak (g) & 247.90 \\
\hline UCS before soak (MPa) & 11.07 \\
\hline UCS after soak (MPa) & 5.11 \\
\hline Water absorption (\%) & 9.04 \\
\hline \% reduction in UCS & 52.93 \\
\hline Open porosity & 0.16 \\
\hline
\end{tabular}

Table 4 shows water absorption test results of a geopolymer sample cured at optimum conditions. The results show a fairly less permeable sample, this may be due to formation of additional cementitious materials in the binder that could fill more voids between sand particles to make more compact matrix. This may have reduced specimen permeability and reduced water absorption by the prepared sample. The sample had a lower water absorption (9\%) in comparison with the permissible limits of $10 \%$ by Huseien et al [51]. The results were consist with work by Kubba et al. [59], the authors concluded that a sample with enough GBFS based binder produces a concrete with good matrix, less porosity and permeability.

\subsection{Toxicity characteristics leaching procedure (TCLP)}


Table 5

TCLP of the specimen cured using optimum conditions.

\begin{tabular}{|lll|}
\hline Element & Concentration (ppm) & $\begin{array}{l}\text { USEPA maximum } \\
\text { allowed concentration } \\
\text { in leachate }(\mathrm{mg} / \mathrm{L}) \text { ) }\end{array}$ \\
\hline $\mathrm{Al}$ & 1,78 & $\mathrm{~N} / \mathrm{A}$ \\
$\mathrm{Ba}$ & 0,082 & 100 \\
$\mathrm{Ca}$ & 7,512 & $\mathrm{~N} / \mathrm{A}$ \\
$\mathrm{Cd}$ & 0,001 & 1 \\
\hline $\mathrm{Cr}$ & 0,043 & 5 \\
\hline $\mathrm{Cu}$ & 0,033 & 5 \\
\hline $\mathrm{Fe}$ & 0,319 & 10 \\
\hline $\mathrm{Mg}$ & 1,036 & $\mathrm{~N} / \mathrm{A}$ \\
\hline $\mathrm{Ni}$ & $-4,43$ & 2 \\
\hline $\mathrm{Mn}$ & 0,036 & 5 \\
\hline $\mathrm{Pb}$ & 0,127 & 5 \\
\hline $\mathrm{Ti}$ & 0,012 & 2 \\
\hline $\mathrm{Zn}$ & 0,104 & 5 \\
\hline
\end{tabular}

Table 4 shows the TCLP results of leachates concentrations from concrete specimen, leachates concentrations were below the recommended limits by USEPA. The low leachates concentration may be mainly due to the ability of the specimen successfully stabilizing toxic elements within the amorphous three-dimensional matrix (3-D) through chemical encapsulation process [60]. The results in agreement with studies reported by Kubba et al. [59]. This TCLP results imply that the produced bricks are environmental friendly and can be used in building and construction.

\section{Conclusions}

The study focused on evaluating the binding properties and the perfomace of GBFS geopolymer by producing building bricks. The waste foundry based specimens possessed good mechanical properties and do not pose any threat of environmental pollution for long-term use. Based on the experimental results the following conclusion can be drawn.

1. The content of the binder, L/S ratio and temperature are the three parameters that affect the mechanical properties of the produced building brick. 
2. Liquid to Solid ratio below optimum causes poor hydrolysis of the solid precursor while high L/S ratio causes voids in the matrix that causes lower UCS.

3. The developed building bricks demonstrated good resistance to water absorption for the entire duration when soaked in water up to the period of 30 days as the absorption percentage was within the acceptable permeability.

4. GBFS-based geopolymers can be used as binders to fabricate building bricks that meet the minimum requirement of ASTM C62-10 that can be used in negligible weathering conditions.

\section{Declarations}

\section{Availability of data and materials}

All data generated or analyzed during this study are available within the article supporting the findings of this study.

\section{Competing interests}

The authors declare they have no competing interests.

\section{Funding}

This work was supported by the NRF (ZA)

\section{Authors' contributions}

N.T. Sithole: Conceptualization, Methodology , Validation,Writing - original draft.

N.T. Tsotetsi: Investigation, data collection. T. Mashifana: Writing - review \& editing. All authors read and approved the final manuscript.

\section{Acknowledgements}

The authors wish to thank NRF for funding this study.

\section{Authors' information (optional)}

\section{References}

1. Singh S., Aswath, M.U. and Ranganath, R.V. Performance assessment of red mud based geopolymer bricks and prisms. J Build Eng. 2020; 101462.

2. Naqi A. and Jang J.G. Recent progress in green cement technology utilizing low-carbon emission fuels and raw materials: A review. Sustainability, 2019; 11(2): 537.

3. Zhang L. Production of bricks from waste materials-A review. Constr Build Mater. 2013; 47: 643-655. 
4. Avtar, R., Tripathi S., Aggarwal A.K. and Kumar P. Population-urbanization-energy Nexus- A review. Res. 2019; 8(3): 136.

5. Nwankwo C.O., Bamigboye G.O., Davies I.E. and Michaels T.A. High volume Portland cement replacement: A review. Constr Build Mater. 2020: 260: 120445.

6. Habert G. Assessing the environmental impact of conventional and 'green'cement production. In EcoEfficient Constr Build Mater. 2014; 199-238. Woodhead Publishing.

7. Singh N.B. and Middendorf, B. Geopolymers as an alternative to Portland cement: An overview. Constr Build Mater. 2020; 237: 117455.

8. Amran Y.M., Alyousef, R., Alabduljabbar H. and El-Zeadani, M. Clean production and properties of geopolymer concrete: A review. J Clean Prod. 2020; 251: 119679.

9. PN M.L., Peter C., Mohan K., Greens S. and George S. Energy efficient production of clay bricks using industrial waste. Heliyon. 2018; 4(10): 00891.

10. Vaverková, M.D. Landfill Impacts on the Environment. 2019; 9(10): 431.

11. Sithole N.T. and Mashifana T. Geosynthesis of building and construction materials through alkaline activation of granulated blast furnace slag. Constr Build Mater. 2020; 264: 120712.

12. Sithole N.T., Okonta F. and Ntuli F. MECHANICAL PROPERTIES AND STRUCTURE OF FLY ASH MODIFIED BASIC OXYGEN FURNACE SLAG BASED GEOPOLYMER MASONRY BLOCKS. J Sol Waste Tech and Manag. 2020; 46(3):372-383.

13. Singh N.B. and Middendorf B. Geopolymers as an alternative to Portland cement: An overview. Constr Build Mater. 2020; 237:117455.

14. Sithole N.T., Okonta F. and Ntuli F. Development of lightweight construction blocks by alkaline activation of bof slag. J Sol Waste Tech Managt. 2019; 45(2): 175-185.

15. Madani H., Ramezanianpour A.A., Shahbazinia M. and Ahmadi E. Geopolymer bricks made from less active waste materials. Constr Build Mater. 2020; 247: 118441.

16. Mashifana T. and Sithole T. Recovery of Silicon Dioxide from Waste Foundry Sand and Alkaline Activation of Desilicated Foundry Sand. J Sust Met 2020; 6(4): 700-714.

17. Sithole N.T. and Mashifana T.P. October. Alkaline solidification of gold mine tailings for production of lightweight masonry blocks. In IOP Conference Series: Mater Sci Eng. 2019; 652(1): 012061. IOP Publishing.

18. Falayi T. Sustainable solidification of ferrochrome slag through geopolymerisation: a look at the effect of curing time, type of activator and liquid solid ratio. Sus Environ Res. 2019; 29(1): 1-10

19. Mashifana T. and Sithole N. POTENTIAL BENEFICIATION OF READILY AVAILABLE GOLD TAILINGS AND PAPER WASTES: DEVELOPMENT OF A NEW BUILDING MATERIAL. J Sol Waste Tech Manag. 2020; 46(3): 350-359.

20. Rafeet A., Vinai R., Soutsos M. and Sha W. Effects of slag substitution on physical and mechanical properties of fly ash-based alkali activated binders (AABs). Cem Concr Res. 2019; 122: 118-135 
21. Merabtene M., Kacimi L. \& Clastres P. Elaboration of geopolymer binders from poor kaolin and dam sludge waste. Heliyon, 2019; 5: 01938.

22. Naghizadeh A., Ekolu S. O. \& Musonda I. High temperature heat - treatment (htht) for partial mitigation of alkali attack in hardened fly ash geopolymer binders. Case Studies in Constr Mater. 2020; 12: 00341.

23. Huseien G. F., Tahir M. M., Mirza J., Ismail M., Shah K. W. and Asaad M. A. Effects of pofa replaced with fa on durability properties of gbfs included alkali-activated mortars. Constr Build Mater. 2018; 175: $174-186$.

24. Murri A.N., Rickard W.D.A., Bignozzi M.C. and Van Riessen A. High temperature behaviour of ambient cured alkali-activated materials based on ladle slag. Cem concr Res. 2013; 43: 51-61.

25. Malhotra S.K. and Tehri S.P. Development of bricks from granulated blast furnace slag. Constr Build Mater. 1996; 10(3): 191-193.

26. Temuujin J.V., Van Riessen A. and Williams R. Influence of calcium compounds on the mechanical properties of fly ash geopolymer pastes. $J$ hazard mater. 2009; 167(1-3): 82-88.

27. Mejía J.M., de Gutiérrez R.M. and Montes C. Rice husk ash and spent diatomaceous earth as a source of silica to fabricate a geopolymeric binary binder. J Clean Prod. 2016; 118: 133-139.

28. Robayo-Salazar R. A., De Gutiérrez M. \& Puertas F. Study of synergy between a natural volcanic pozzolan and a granulated blast furnace slag in the production of geopolymeric pastes and mortars. Constr Build Mater. 2017; 157: 151-160.

29. Rashad A. M. Metakaolin as cementitious material: History, scours, production and composition - a comprehensive overview. Constr Build Mater. 2013; 41: 303-318.

30. Falah M., Ohenoja K., Obenaus-Emler R., Kinnunen P. and Illikainen M. Improvement of mechanical strength of alkali-activated materials using micro low-alumina mine tailings. Constr Build Mater. 2020; 248: 118659.

31. Tekin I., Gencel O., Gholampour A., Oren O.H., Koksal F. and Ozbakkaloglu T. Recycling zeolitic tuff and marble waste in the production of eco-friendly geopolymer concretes. J Clean Prod. 2020; 268: 122298.

32. Yasaswini K. and Rao A.V. Behaviour of geopolymer concrete at elevated temperature. Materials Today: Proc. 2020; 33: 239-244.

33. Sabour M.R., Derhamjani G., Akbari, M. et al. Global trends and status in waste foundry sand management research during the years 1971-2020: a systematic analysis. Envir Sci Pol Res.

34. Ntuli F. and Okonta F.N. Desilication of fly ash and geotechnical applications of the desilicated fly ash. 2016.

35. Quijorna N., Miguel G.S. and Andrés A. Incorporation of Waelz slag into commercial ceramic bricks: a practical example of industrial ecology. Industr Eng Chem Res. 2011; 50(9): 5806-5814.

36. Fahim Huseien G., Mirza J., Ismail M., Ghoshal, S. K. and Abdulameer Hussein A. Geopolymer mortars as sustainable repair material: A comprehensive review. Renew Sust Ener Rev. 2017; 80: 54- 
37. Yalley P. Effect of sand fines and water/cement ratio on concrete properties. J Civ Eng Res. 2018; 4.

38. Makul N. and Sokrai P. Influences of fine waste foundry sand from the automobile engine-part casting process and water-cementitious ratio on the properties of concrete: A new approach to use of a partial cement replacement material. J Build Eng. 2018; 20: 544-558.

39. Phoo-Ngernkham T., Maegawa A., Mishima N., Hatanaka S. and Chindaprasirt P. Effects of sodium hydroxide and sodium silicate solutions on compressive and shear bond strengths of fa-gbfs geopolymer. Constr Build Mater. 2015; 91: 1-8.

40. Nath S. K. Fly ash and zinc slag blended geopolymer: Immobilization of hazardous materials and development of paving blocks. J Hazard Mater. 2020; 387: 121673.

41. Yankwa Djobo J. N., Elimbi A., Kouamo Tchakouté H. and Kumar S. Mechanical properties and durability of volcanic ash based geopolymer mortars. Constr Build Mater. 2016; 124: 606-614.

42. Muttashar H. L., Ariffin M. a. M., Hussein M. N., Hussin M. W. and Ishaq S. B. Self-compacting geopolymer concrete with spend garnet as sand replacement. J Build Eng. 2018; 15: 85-94.

43. Kaze R. C., À Moungam L. M. B., Cannio M., Rosa R., Kamseu E., Melo U. C. and Leonelli C. Microstructure and engineering properties of fe2o3 (feo)-al2o3-sio2 based geopolymer composites. $J$ Clean Prod. 2018b; 199: 849-859.

44. Kaze C. R., Djobo J. N. Y., Nana A., Tchakoute H. K., Kamseu E., Melo U. C., Leonelli C. and Rahier H. Effect of silicate modulus on the setting, mechanical strength and microstructure of iron-rich aluminosilicate (laterite) based-geopolymer cured at room temperature. Cer Int. 2018a; 44: 2144221450.

45. Sontia Metekong J. V., Kaze C. R., Deutou J. G., Venyite P., Nana A., Kamseu E., Melo U. C. and Tatietse T. T. Evaluation of performances of volcanic-ash-laterite based blended geopolymer concretes: Mechanical properties and durability. J Build Eng. 2021; 34: 101935.

46. Kaze R., À Moungam L. B., Djouka M. F., Nana, A., Kamseu E., Melo U. C. and Leonelli C. The corrosion of kaolinite by iron minerals and the effects on geopolymerization. Appl Clay Sci. 2017; 138: 48-62.

47. Tchakouté H. K., Fotio D., Rüscher C. H., Kamseu E., Djobo J. N., Bignozzi M. C. and Leonelli C. The effects of synthesized calcium phosphate compounds on the mechanical and microstructural properties of metakaolin-based geopolymer cements. Constr Build Mater. 2018; 163: 776-792.

48. Shoaei P., Musaeei H. R., Mirlohi F., Narimani Zamanabadi S., Ameri F. and Bahrami N. Waste ceramic powder-based geopolymer mortars: Effect of curing temperature and alkaline solution-to-binder ratio. Constr Build Mater. 2019;227: 116686.

49. Koutník P., Soukup A., Bezucha P., Šafář J. and Kohout, J. Low viscosity metakaolinite based geopolymer binders. Constr Build Mater. 2020; 230: 116978.

50. Samantasinghar S. \& Singh S. P. Effect of synthesis parameters on compressive strength of fly ashslag blended geopolymer. Constr Build Mater. 2018; 170: 225-234. 
51. Huseien G., Mirza J., Mohmmed I. and Hussin M. Influence of different curing temperatures and alkali activators on properties of gbfs geopolymer mortars containing fly ash and palm-oil fuel ash. Constr Build Mater. 2016; 125: 1229-1240.

52. Rodrigue Kaze C., Ninla Lemougna P., Alomayri T., Assaedi H., Adesina A., Kumar Das S., LecomteNana G.-L., Kamseu E., Chinje Melo U. and Leonelli C. Characterization and performance evaluation of laterite based geopolymer binder cured at different temperatures. Constr Build Mater. 2020: 121443.

53. Tian X., Xu W., Song S., Rao F. and Xia L. Effects of curing temperature on the compressive strength and microstructure of copper tailing-based geopolymers. 2020; 253: 126754

54. Guo X. and Xiong G. Resistance of fiber-reinforced fly ash-steel slag based geopolymer mortar to sulfate attack and drying-wetting cycles. Constr Build Mater. 2020; 121326.

55. Jang J. G., Lee N. and Lee H.-K. Fresh and hardened properties of alkali-activated fly ash/slag pastes with superplasticizers. Constr Build Mater. 2014; 50: 169-176.

56. Ren W., Xu J., Liu J. and Su H. Dynamic mechanical properties of geopolymer concrete after water immersion. Cer Int. 2015; 41: 11852-11860.

57. Aygörmez Y., Canpolat O. and Al-Mashhadani M. M. Assessment of geopolymer composites durability at one year age. J Build Eng. 2020; 32: 101453.

58. Vafaei M., Allahverdi A., Dong P. and Bassim N. Acid attack on geopolymer cement mortar based on waste-glass powder and calcium aluminate cement at mild concentration. Constr Build Mater. 2018; 193: 363-372.

59. Kubba Z., Fahim Huseien G., Sam A. R. M., Shah K. W., Asaad M. A., Ismail M., Tahir M. M. and Mirza $\mathrm{J}$. Impact of curing temperatures and alkaline activators on compressive strength and porosity of ternary blended geopolymer mortars. Case Studies in Constr Mater. 2018; 9: 00205.

60. Komnitsas K., Zaharaki D. and Bartzas G. Effect of sulphate and nitrate anions on heavy metal immobilisation in ferronickel slag geopolymers. Appl Clay Sci. 2013; 73: 103-109.

\section{Figures}




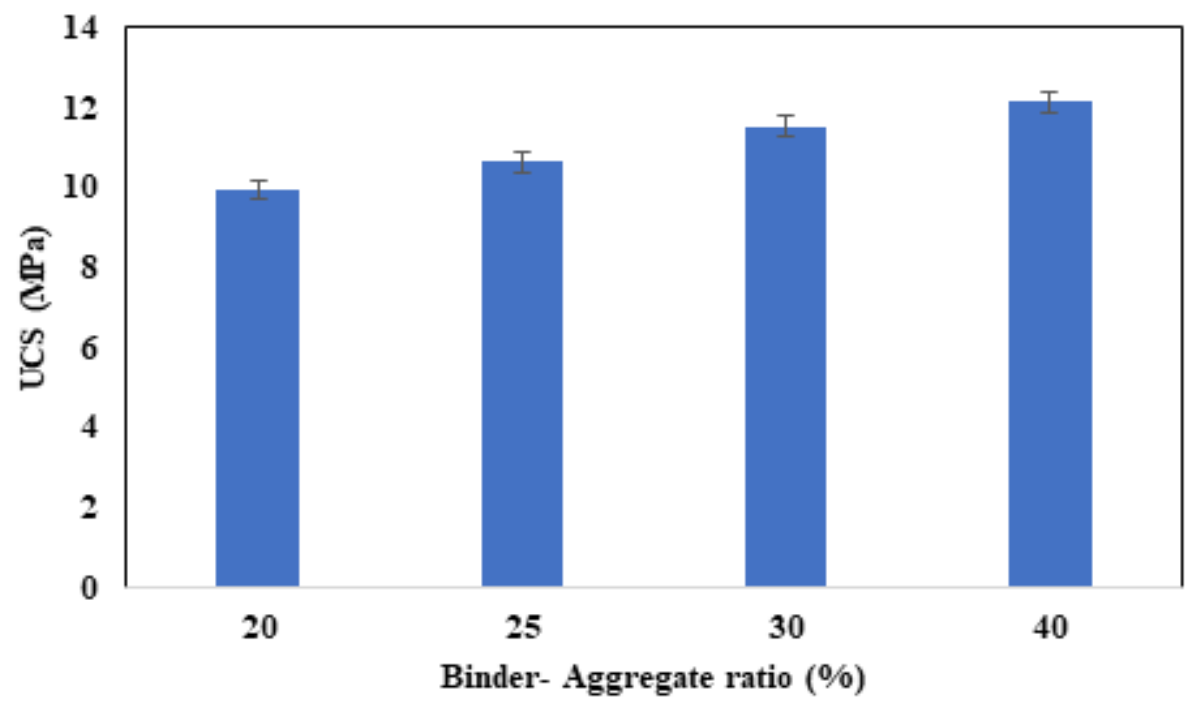

Figure 1

Effect of binder and aggregate ratio on UCS 

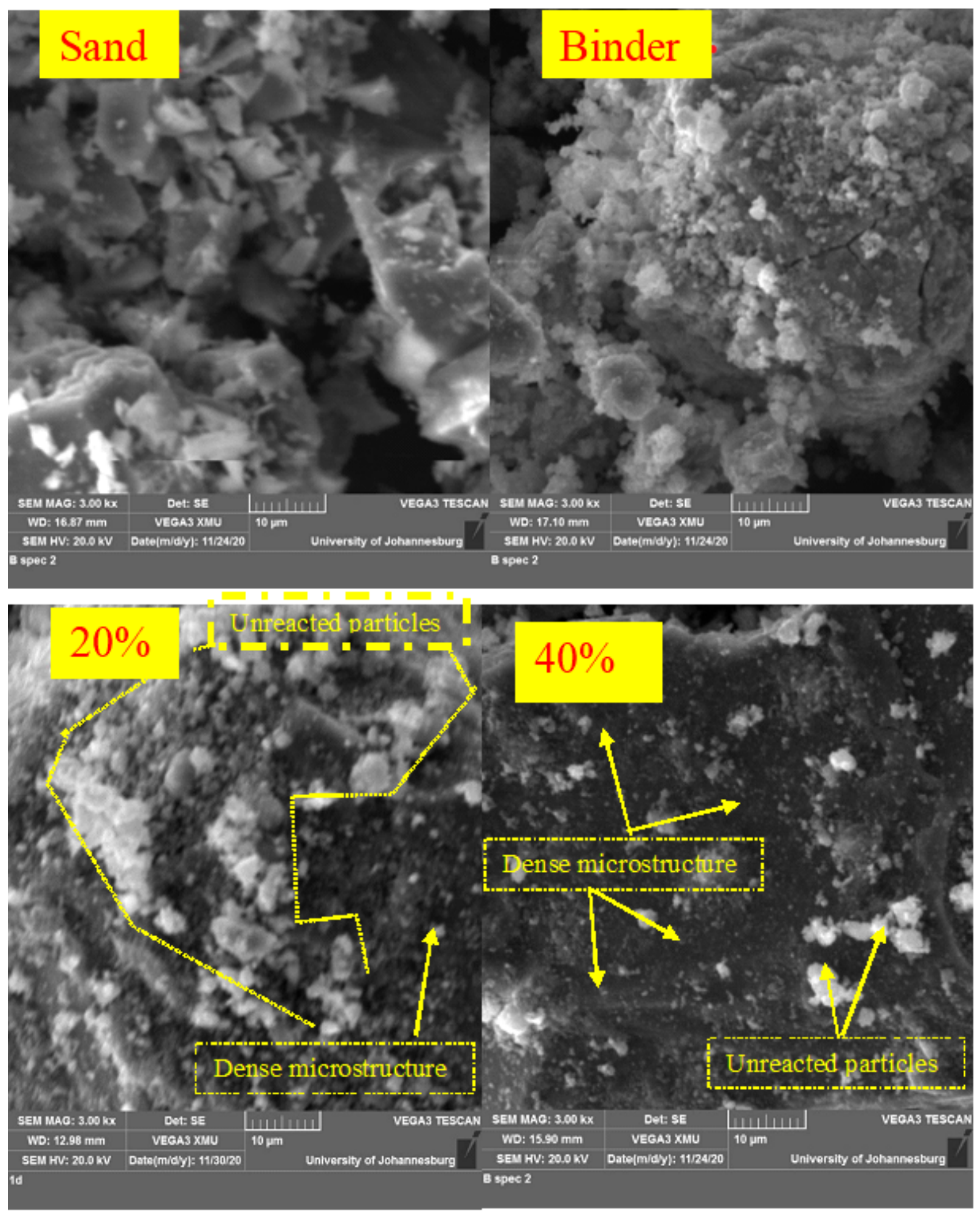

\section{Figure 2}

SEM analysis of concrete samples with different binder to aggregate ratio 


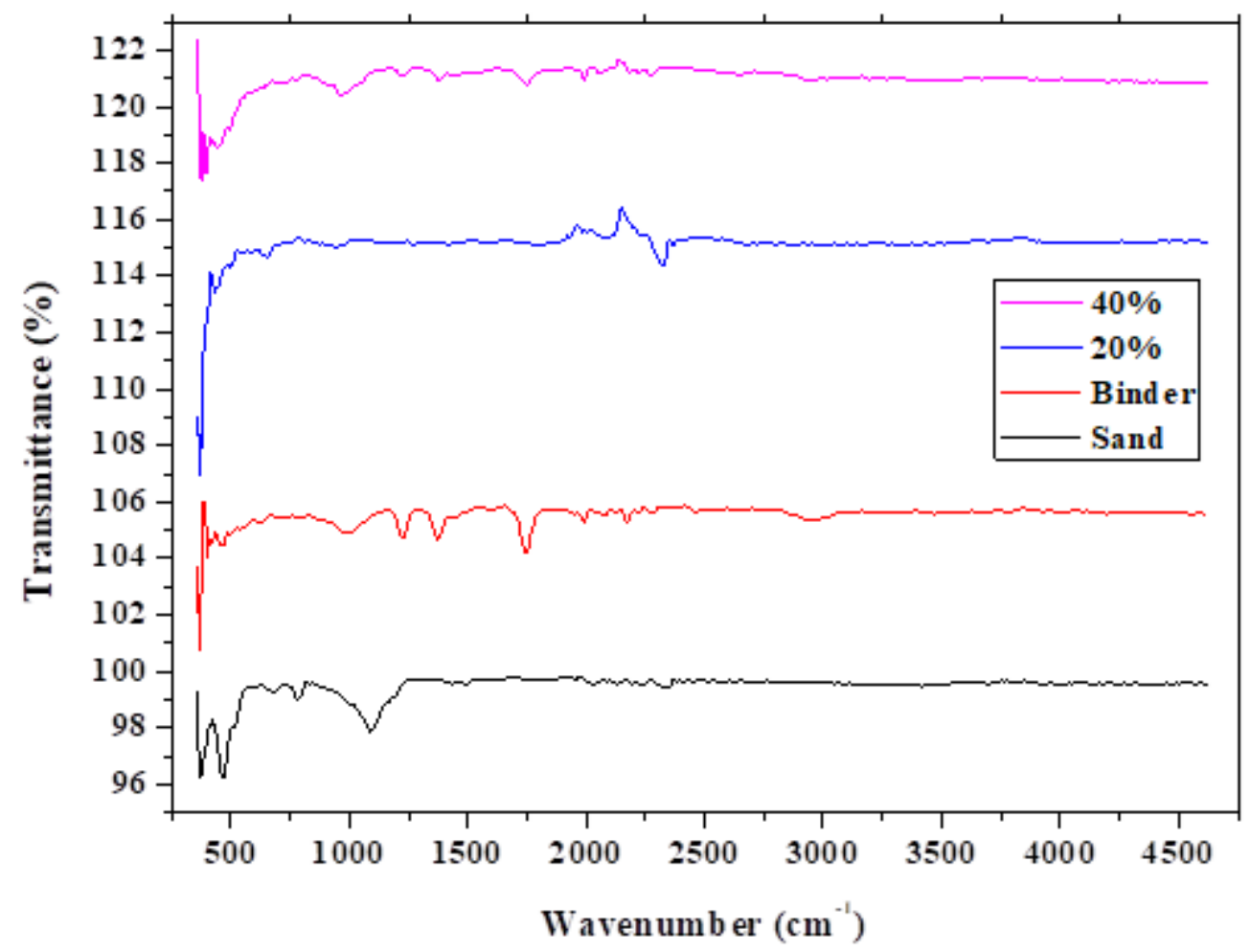

Figure 3

FTIR analysis of concrete samples with different binder to aggregate ratio

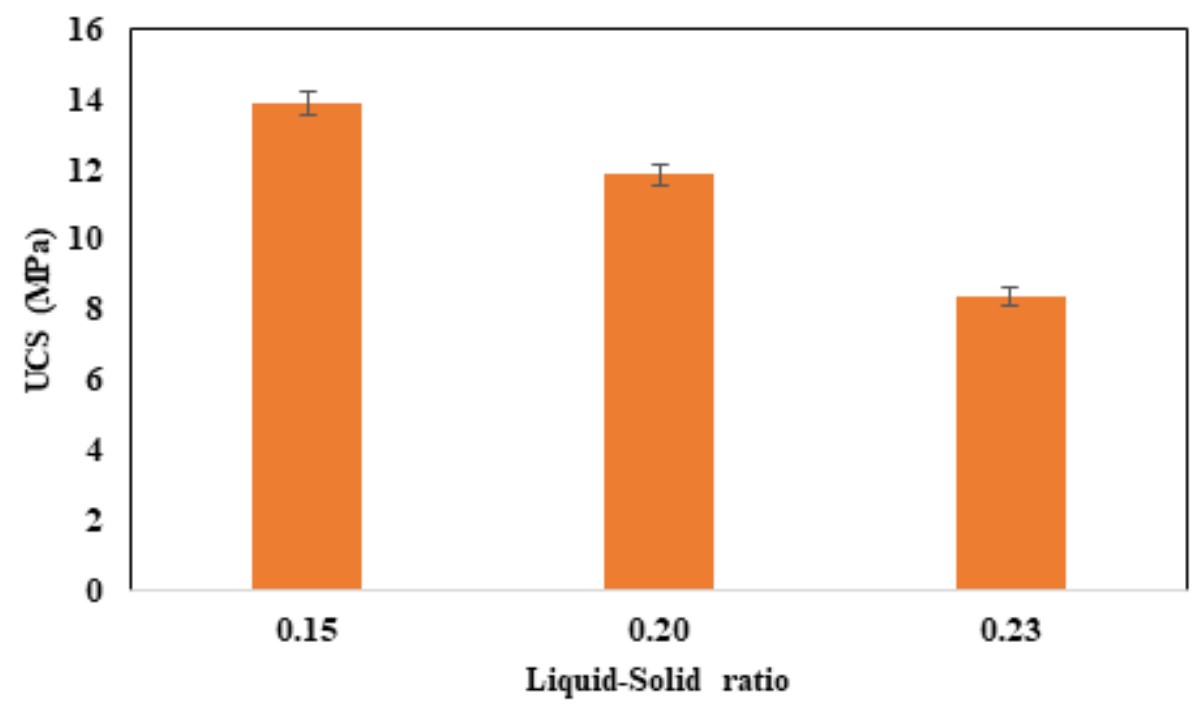

Figure 4

Effect of L/S ratio on UCS of geopolymeric specimens 


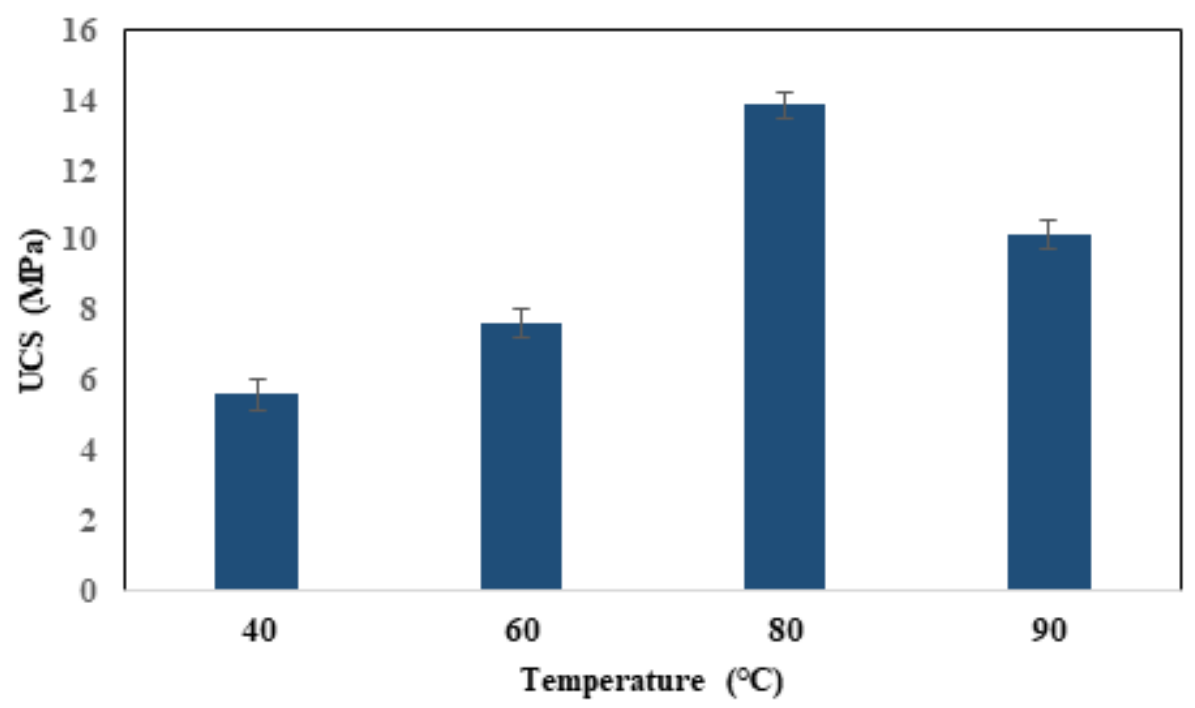

Figure 5

UCS results of geopolymer concrete samples cured at different temperatures. 

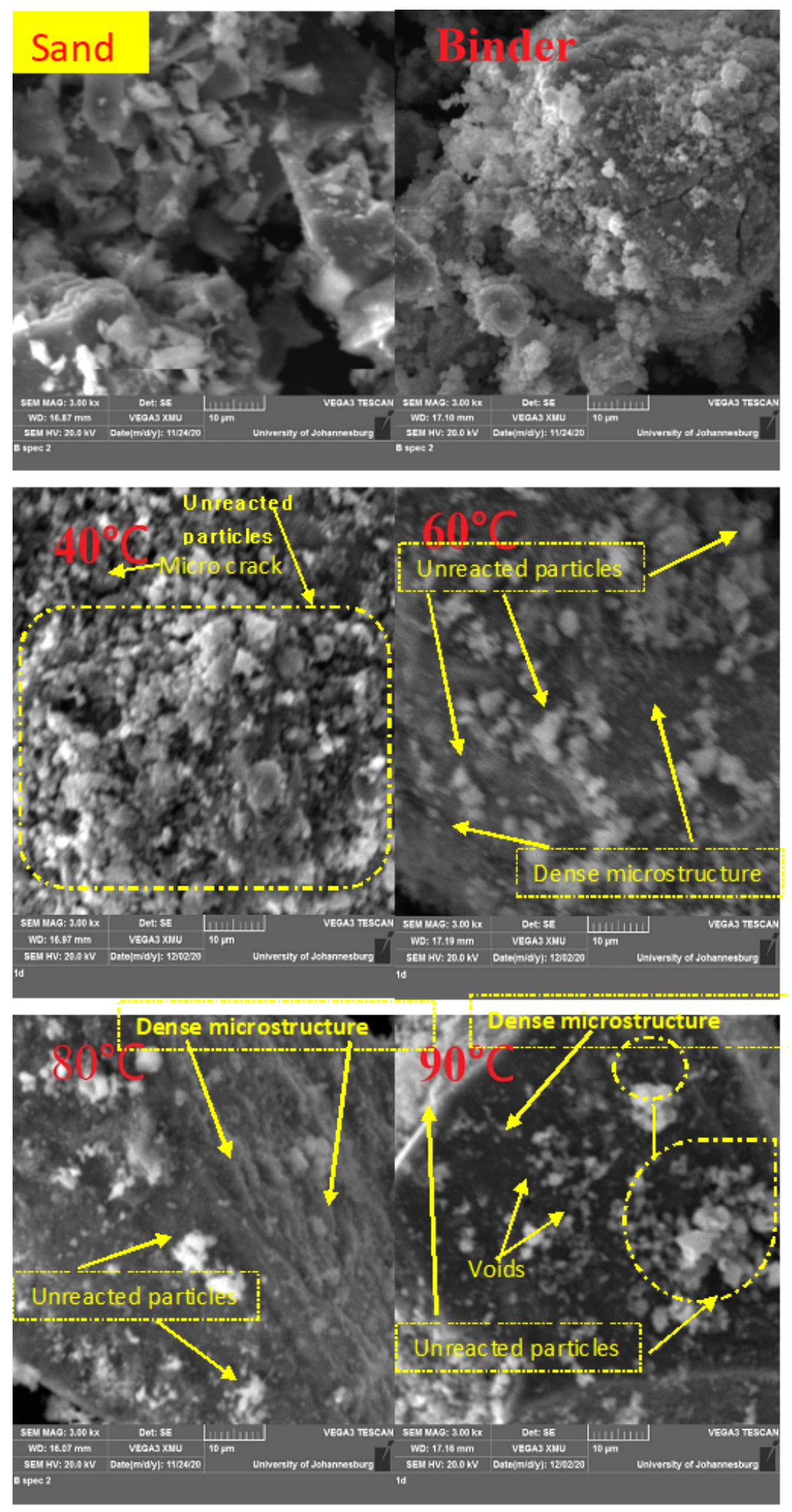

\section{Figure 6}

SEM analysis of samples with varied curing temperature 


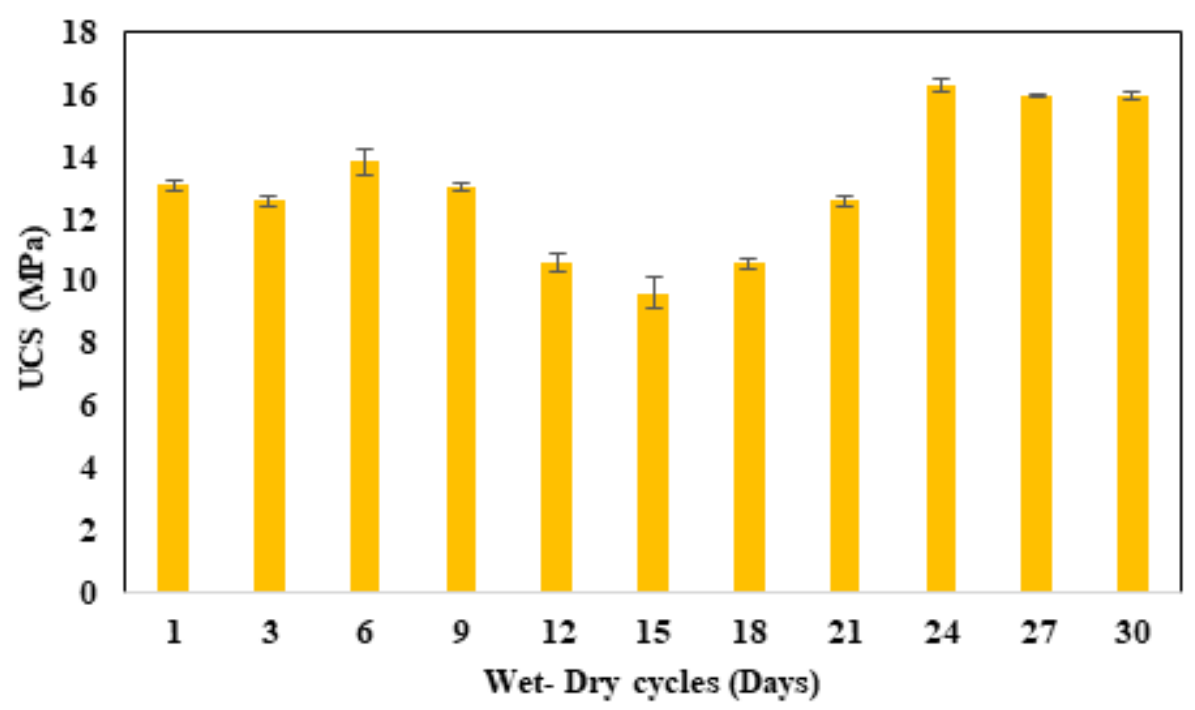

Figure 7

Effect of wet-dry cycles on concrete samples on UCS

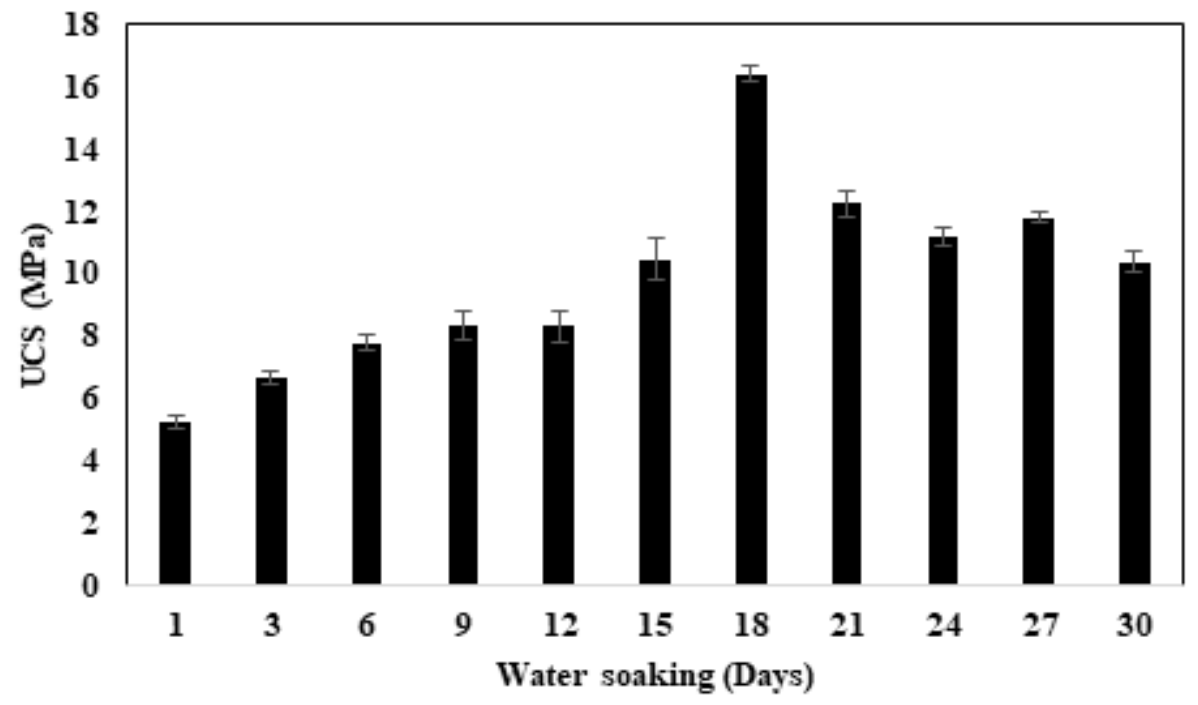

Figure 8

The effect of water soaking of concrete samples on UCS 


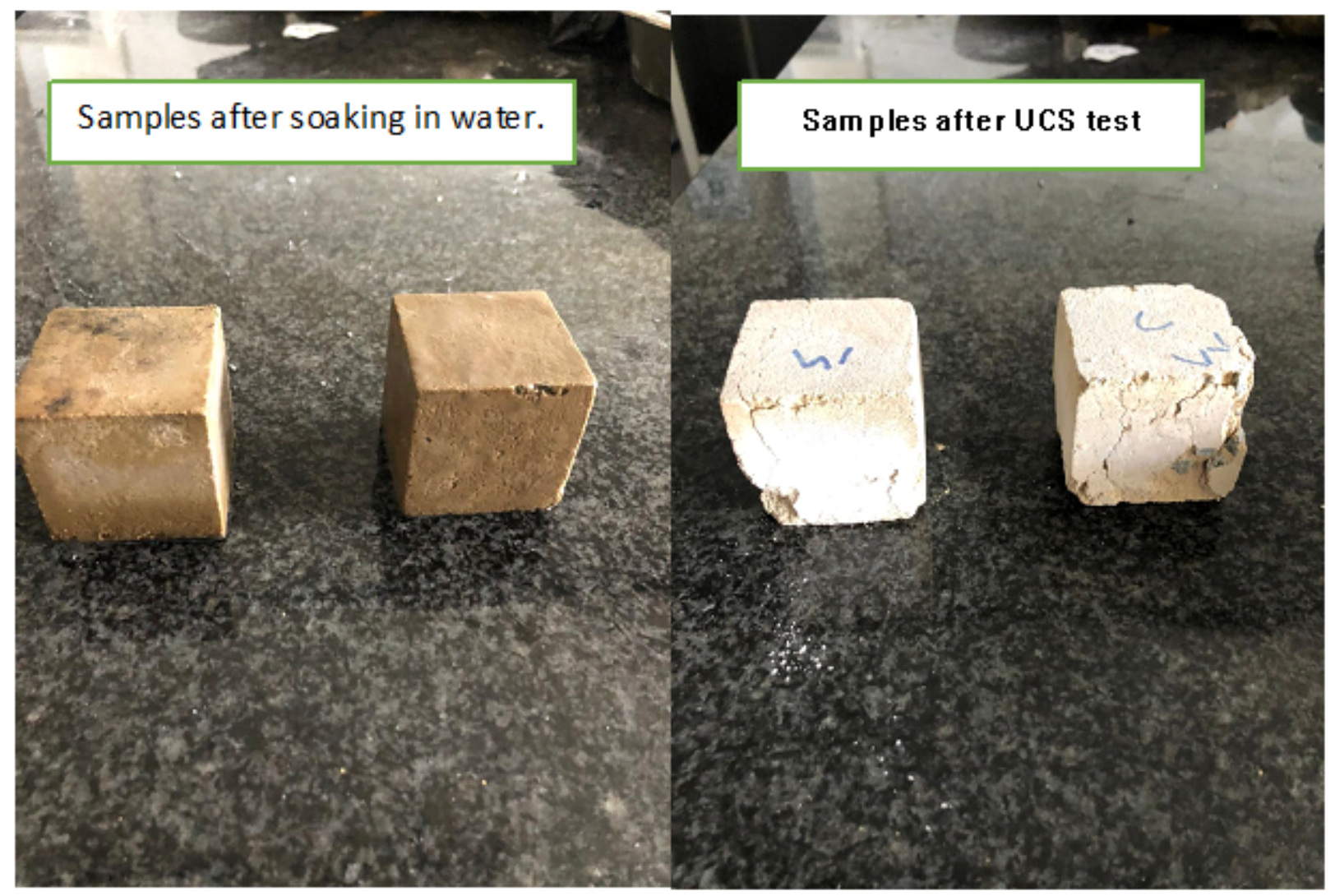

Figure 9

Images of samples after immersion in water for 30 days

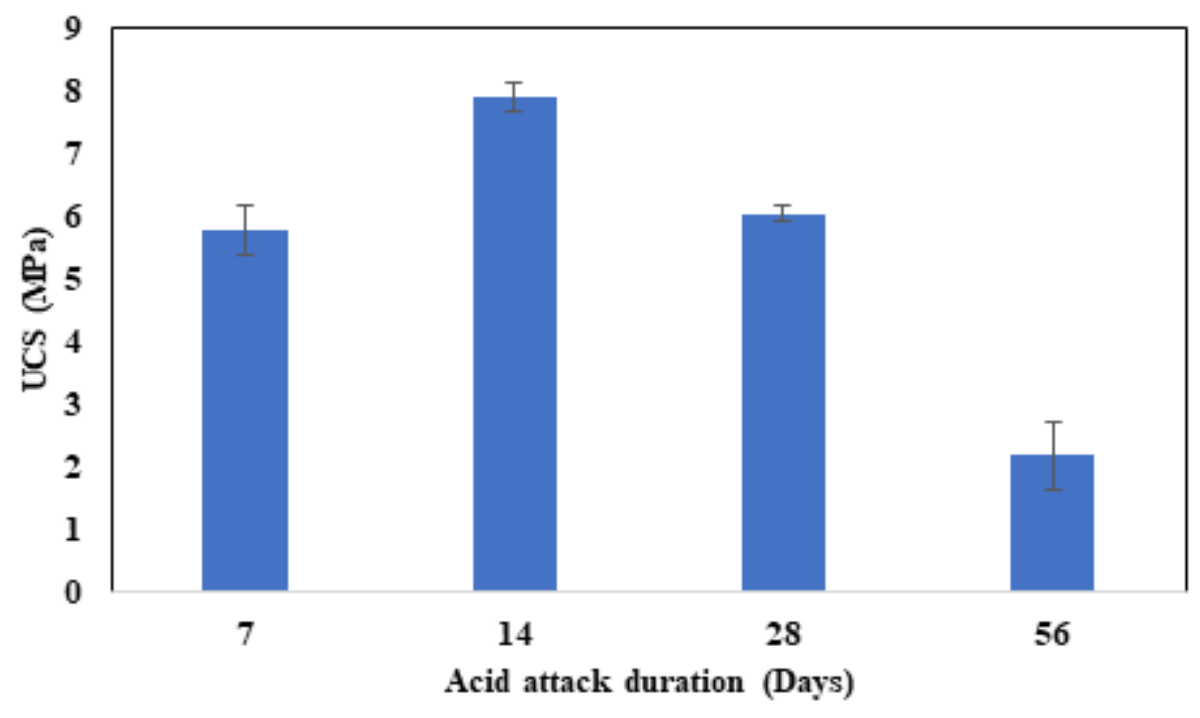

Figure 10

The effect of acid attack of concrete samples on UCS 


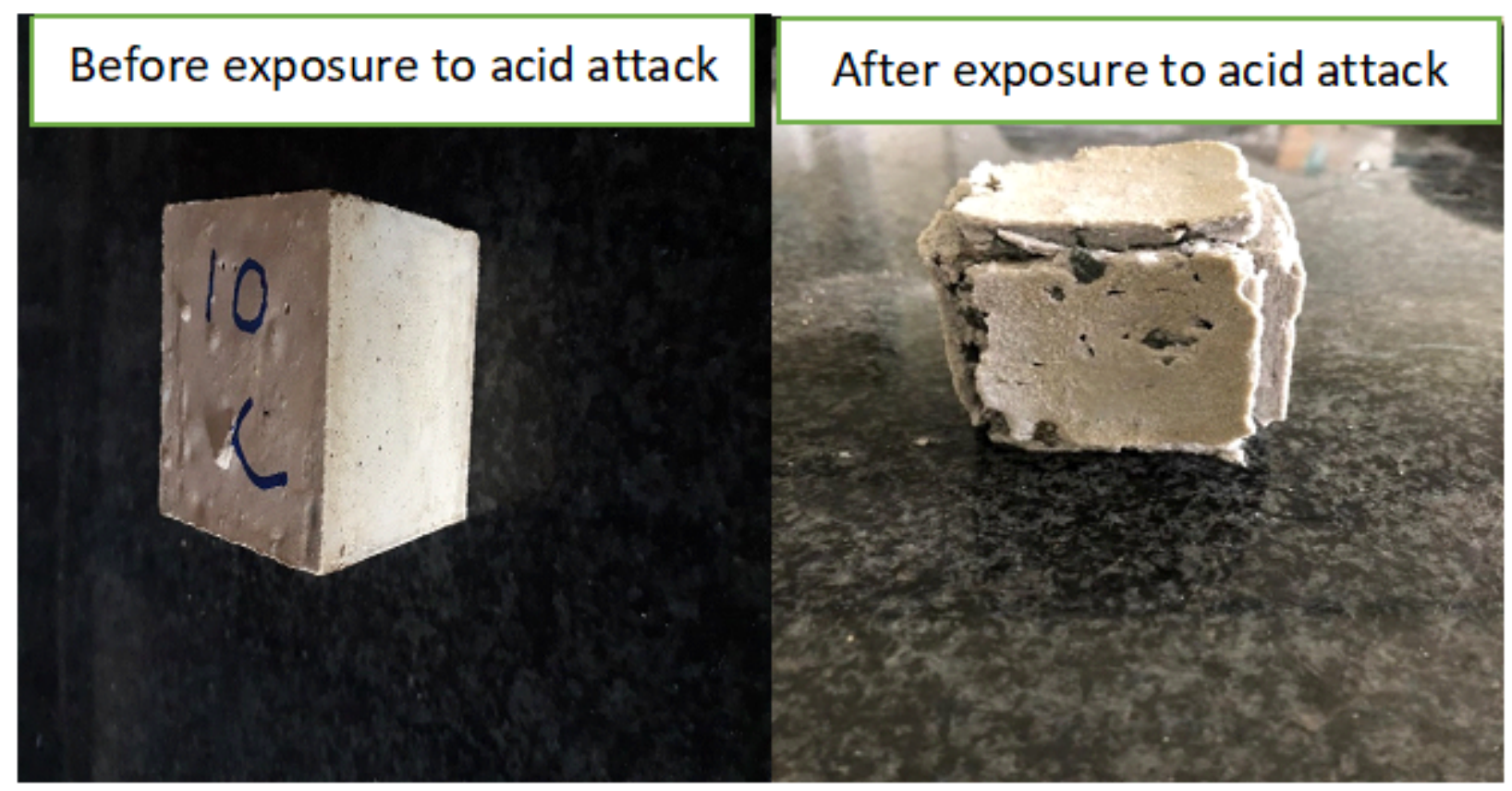

Figure 11

The images of specimen of before and after acid attack 